\title{
A tápláltsági állapot felmérése és jelentősége krónikus obstruktív tüdőbetegségben
}

\author{
Fekete Mónika dr. ${ }^{1}$. Pákó Judit dr. ${ }^{2}$ - Szőllősi Gergő ${ }^{3}$. Tóth Krisztina ${ }^{2}$ \\ Szabó Mónika ${ }^{2}$ - Horváth Dorottya ${ }^{2}$ - Varga János Tamás dr. ${ }^{2}$ \\ ${ }^{1}$ Semmelweis Egyetem, Általános Orvostudományi Kar, Népegészségtani Intézet, Budapest \\ ${ }^{2}$ Országos Korányi Pulmonológiai Intézet, Budapest \\ ${ }^{3}$ Debreceni Egyetem, Népegészségügyi Kar, Családorvosi és Foglalkozás-egészségügyi Tanszék, Debrecen
}

Bevezetés: COPD-ben szenvedő betegeknél kóros tápláltsági állapot alakulhat ki a gyulladásos citokinek termelődése, valamint a beszúkült étrend miatt.

Célkitüzés: A COPD-s betegek tápláltsági állapotának kombinált rizikószưrése, a testtömeg rendellenességének és kapcsolatának vizsgálata a légzőszervi és funkcionális paraméterekkel, valamint e rendellenességek életminőségre gyakorolt hatásának elemzése.

Módszer: A tápláltsági rizikó kombinált szűrését végeztük MUST (Malnutrition Universal Screening Tool) kérdőívvel és a bioelektromosimpedancia-analízis elvén múködő InBody 170 géppel, valamint OMRON BF511 testösszetételelemző mérókészülékkel az Országos Korányi Pulmonológiai Intézet Légzésrehabilitációs Osztályán 2019. január 1. és december 31. között, 40 év feletti COPD-s betegek körében.

Eredmények: A betegek medián életkora 66 (IQR 61-72) év, a medián BMI 24,5 (IQR 19,1-29,7) kg/m² volt; a 110 COPD-s beteg közül 32\% ( $\mathrm{n}=35)$ alultáplált volt, és $45 \%(\mathrm{n}=49)$ akaratlanul fogyott az előző évben. Az alultáplált betegek gyengébb tüdőfunkcióval rendelkeztek (FEV ${ }_{1}$ ref\%: 36 [IQR 29-49]), mint a normál súlyú (FEV ${ }_{1}$ ref\%: 46 [IQR 35-52]) vagy túlsúllyal rendelkező ( $\mathrm{FEV}_{1}$ ref\%: 46 [IQR 39-57]) betegek, életminőségük szignifikánsan gyengébb volt $(65,63$ vs. 56,59 vs. 47,$23 ; \mathrm{p}=0,045)$. Szignifikáns korrelációt találtunk a BMI $-\mathrm{FEV}_{1}$ ref\% $(p=0,26$; $\mathrm{p}=0,007)$ és a BMI - exacerbatiók száma között $(p=0,37 ; \mathrm{p}=0,008)$.

Következtetés: Megállapítottuk, hogy az alultáplált COPD-s betegek gyengébb tüdőfunkcióval és rosszabb életminőséggel rendelkeznek, valamint azt is, hogy a kóros tápláltsági állapot kialakulásának magas kockázata miatt COPD-s betegeknél javasoljuk a tápláltsági állapot rizikójának kombinált szűrését és a táplálásterápia hatékonyságának vizsgálatát.

Orv Hetil. 2020; 161(40): 1711-1719.

Kulcsszavak: COPD, tápláltsági állapot, BMI, testzsírszázalék, izomszázalék

\section{Significance of nutritional status in chronic obstructive pulmonary disease: a survey}

Introduction: Malnutrition is a common finding in patients with COPD due to overproduction of inflammatory cytokines as well as nutritional deficiencies.

Objective: Our primary aim was to assess the combined risk factors of malnutrition in COPD patients. Abnormalities in patients' body mass index were compared with pulmonary function tests and quality of life.

Method: We performed a combined nutrition status risk screening using an anonymous questionnaire survey, Malnutrition Universal Screening Tool, and bioelectrical impedance analysis (using InBody 170 and OMRON BF511) in Budapest at the Department of Pulmonary Rehabilitation of the National Institute of Pulmonology between 01 January 2019 and 31 December 2019.

Results: Median patient age was 66 (IQR 61-72) years and median BMI was 24.5 (IQR 19.1-29.7) kg/m². Of the 110 patients enrolled, $35(32 \%)$ were malnourished and $49(45 \%)$ reported unintended weight loss in the previous 12 months. Patients with malnutrition had significantly lower pulmonary function $\left(\mathrm{FEV}_{1} \mathrm{ref} \%\right.$ : 36 [IQR 29-49]) when compared with patients with a normal BMI (FEV $\mathrm{Fef}_{1}$ : 46 [IQR 35-52]) and elevated BMI (FEV $\mathrm{ref} \%: 46$ [IQR 39-57]), and their quality of life was significantly lower (65.63 vs. 56.59 vs. $47.23 ; \mathrm{p}=0.045)$. BMI was correlated with $\mathrm{FEV}_{1} \mathrm{ref} \%(p=0.26 ; \mathrm{p}=0.007)$, and the number of exacerbations $(p=0.37 ; \mathrm{p}=0.008)$. 
Conclusion: Our results showed that COPD patients with malnutrition had worse quality of life, when compared with patients with normal or elevated BMI. Based on these findings, assessment for risk factors of malnutrition and monitoring of the efficiency of nutritional therapy is recommended in patients with COPD.

Keywords: COPD, nutritional status, BMI, body fat percentage, muscle mass percentage

Fekete M, Pákó J, Szőllősi G, Tóth K, Szabó M, Horváth D, Varga JT. [Significance of nutritional status in chronic obstructive pulmonary disease: a survey]. Orv Hetil. 2020; 161(40): 1711-1719.

(Beérkezett: 2020. március 31.; elfogadva: 2020. május 3.)

\begin{abstract}
Rövidítések
$6 \mathrm{MWD}=(6$ minute walking distance $) 6$ perces sétatávolság; AECOPD $=$ COPD akut exacerbatio; BIA = bioelektromosimpedancia-analízis; $\mathrm{BMI}=($ body mass index $)$ testtömegindex; $\mathrm{COPD}=($ chronic obstructive pulmonary disease $)$ krónikus obstruktív tüdőbetegség; $\mathrm{FEV}_{1}=$ (forced expiratory volume in the first second) erőltetett kilégzés első másodpercében kifújt volumen; FVC = (forced vital capacity) eróltetett kilégzési vitálkapacitás; GOLD = (Global Initiative for Obstructive Lung Disease) a COPD súlyossági fokát besoroló nemzetközi ajánlás; $\mathrm{HDL}=$ (high-density lipoprotein $)$ magas sưrúségú lipoprotein; $\mathrm{IQR}=$ (interquartile range) interkvartilis terjedelem; LDL = (low-density lipoprotein) alacsony sûrúségú lipoprotein; mMRC $=($ modified Medical Research Council $)$ a Brit Mellkasi Társaság módosított nehézlégzésskálája; MUST = (Malnutrition Universal Screening Tool) a malnutritio univerzális szűrési módszere; NHLBI = National Heart, Lung, and Blood Institute; SGRQ = St George's Respiratory Questionnaire (SzentGyörgy-féle Légzési Kérdőív); TUKEB = Tudományos és Kutatásetikai Bizottság; WHO = World Health Organization
\end{abstract}

A COPD megelőzhető és kezelhető népbetegség, amelyet perzisztáló és általában progresszív bronchialis obstrukció jellemez [1]. A légúti áramlási ellenállás fokozódása a tüdőnek a szövetkárosító gázok és részecskék inhalációja (leginkább a dohányzás) hatására kialakuló, kórosan fokozott gyulladásos reakciójának következménye [2]. A COPD morbiditása a felnőtt lakosság legalább 6\%-át érinti, és becslések szerint 2030-ra a harmadik leggyakoribb halálokká válik [3]. A COPD világszerte aluldiagnosztizált betegség; a COPD-prevalencia különbségei a világban nagyok: USA: 8,5-19,6\%, Mexikó: 20\%, Kína: 3,9-13,7\%, India: 12,5\%, Hollandia: 3\%, Ausztria: 26,1\% [4]. Magyarországon a tüdőgyógyászati hálózatban nyilvántartott betegek prevalenciája 2004ben még 1\% alatt volt, 2014-ben 1,8\%, mára 1,96\% (a nyilvántartott betegek száma: 193553 fó), ami meszsze alatta marad az 500 000-re becsült betegszámnak; mintegy a harmadukat ismerjük, $s$ a betegek változó együttmúködése miatt gyakori az állapotuk rosszabbodása [4].

Az alultápláltság gyakori (10-45\%) a COPD-s betegek körében, s gyakran rossz prognózissal társul [5]; ennél még magasabb lehet az alacsony és közepes jövedelmú országokban [6]. Az alultápláltság befolyásolja a légzésfunkciót, rontja az életminőséget, növeli az exacerbatiók számát és kockázatát, a kórházi tartózkodás hosszát és az egészségügyi költségeket $[7,8]$. A nem megfelelő táplálékbevitel az alultápláltság leggyakrabban említett oka a COPD-s betegek körében [9], de ezen kívül kialakulásának okai között szerepelhet az étvágytalanság, az infekció, a gyógyszermellékhatás (antibiotikumok, teofillin, xantinszármazékok), az evést akadályozó légszomj, a légzési elégtelenség okozta felszívódási zavar, a depreszszió, de akár a kórházi környezet hatása is közrejátszhat a kialakulásában [10]. Korábbi kutatások rávilágítanak arra, hogy az időben kiszúrt és megkezdett táplálásterápia jelentős javulást eredményezhet a légzésfunkcióban, a terhelési toleranciában és az életminőségben is, valamint csökkentheti a COPD-s betegek morbiditását és mortalitását [11]. Tanulmányunk célja a COPD-s betegek tápláltsági állapota kombinált rizikószúrési eredményének bemutatása, a testtömeg rendellenességének és kapcsolatának vizsgálata a légzőszervi és funkcionális paraméterekkel, valamint e rendellenességek életminőségre gyakorolt hatásának elemzése.

\section{Módszer}

Az Országos Korányi Pulmonológiai Intézet COPD-s betegeinél végeztünk keresztmetszeti vizsgálatot. A betegek a felmérés előtt szóbeli és írásbeli tájékoztatást kaptak, majd aláirták a beleegyező nyilatkozatot. A vizsgálatot a TUKEB jóváhagyta (engedélyszám: TUKEB 44402-2/2018/EKU), a kutatás megfelel a Helsinki Deklarációban foglaltaknak. A vizsgálatba történő bevonás kritériumai: 40 év feletti életkor, diagnosztizált COPD (post-bronchodilator $\mathrm{FEV}_{1} / \mathrm{FVC}<70 \%$ ). A kizárás kritériumai: beültetett pacemaker, implantáció, protézis, nóknél várandósság, súlyos dehidrációs állapot vagy ödéma jelenléte, egyéb krónikus (például daganatos, endokrin) betegségek, amelyek a tápláltsági állapot eszközös mérésének eredményét nagymértékben befolyásolják. A COPD egyéb társbetegségei, mint egy 'reallife' vizsgálatban - például a cardiovascularis betegségek (atherosclerosis, hypertonia, ischaemiás szívbetegség), 
diabetes, osteoporosis, szorongás, depresszió - nem voltak kizáró tényezői a vizsgálatnak.

A tápláltsági állapot rizikójának kombinált szưrését végeztük Malnutrition Universal Screening Tool (MUST) kérdőíves felméréssel [12] és a bioelektromosimpedancia-analízis (BIA) elvén múködő InBody 170 géppel (gyártó: BridgePower Corp., Gyeonggi-Do, Dél-Korea; Modell: JMWl40KAl240F02), valamint OMRON BF511 (Gyártó: OMRON Healthcare, Kiotó, Japán; Modell: OM31-HBF-511B-E) testösszetétel-elemző mérőkészülékkel. A MUST-kérdőív által vizsgált szempontok és azok értékelése: BMI szerint $(0$ pont, ha BMI $>20 \mathrm{~kg} / \mathrm{m}^{2} ; 1$ pont, ha BMI $=18,5-20 \mathrm{~kg} / \mathrm{m}^{2}$; 2 pont, ha $\left.B M I<18,5 \mathrm{~kg} / \mathrm{m}^{2}\right)$; a testtömegcsökkenés mértéke szerint $(0$ pont, ha $<5 \%$; l pont, ha $5-10 \%$; 2 pont, ha $>10 \%)$ és az akut betegség táplálékbevitelre tett hatása szerint $(0$ pont, ha nincs akut betegség és megfelelő a tápanyagbevitel; különben 2 pont). Az így kapott pontszámok összegének értékelése: a 0 pont alacsony rizikót, az l pont közepes rizikót és a 2-6 pont magas rizikót mutat. A MUST-kérdőív gyengesége, hogy BMI-alapú, azaz nem veszi figyelembe a testösszetételt - ennek kompenzálására testösszetétel-analizálást is végeztünk egy InBody 170 és egy OMRON BF511, sok frekvencián mérô orvostechnikai eszközzel, melyek mérik a testtömeget, s elvégzik a testzsírszázalék, az izomszázalék, a testtömegindex számítását is. A bioelektromos ellenállás mérésén alapuló testösszetételbecslés nem invazív eljárás, mely a szervezetben a zsíros és sovány testtömeget, valamint a víztartalmat becsüli meg. Az eszközhasználat előtt az alábbi szempontokra ügyeltünk: a beteg legyen reggel éhgyomorra (vagy minimum két órával előtte ne egyen és ne igyon), a mérés vizeletürítés után, lehetőleg székletürítés után, fehérnemúben, mezítláb történjen (fém ékszerek nélkül), a beteg előtte ne végezzen megerôltető fizikai aktivitást, és nőknél kerülendő a menstruációs időszak. Szintén figyeltünk a megfelelő testhelyzetre (elhelyezkedés a méröpontokon, a karok ne érjenek a törzshöz) és a megfelelő szobahő-mérsékletú helyszínre is. A tápláltsági állapot markerei közül a teljes testtömeget, az ebból származtatott BMI-t, a testzsírszázalékot, az izomszázalékot és az alapanyagcsere értékét vizsgáltuk. A BMI-t a testtömeg és a testmagasság négyzetének hányadosával számoltuk $\left(\mathrm{kg} / \mathrm{m}^{2}\right)$, majd a BMI alapján a betegeket három csoportra osztottuk: normál súlyú $\left(B M I=21-25 \mathrm{~kg} / \mathrm{m}^{2}\right)$, túlsúlyos/elhízott kategóriára (BMI>25 $\left.\mathrm{kg} / \mathrm{m}^{2}\right)$, és alultáplált csoportra $\left(B M I<21 \mathrm{~kg} / \mathrm{m}^{2}\right)$. Ez a besorolás az NHLBI osztályozásán alapul [13], mert COPD-ben szenvedő betegeknél a $\mathrm{BMI}<2 \mathrm{l} \mathrm{kg} / \mathrm{m}^{2}$ esetén már fokozódik a halálozási kockázat, és táplálásterápia bevezetése indokolt, ami egybevág a COPD súlyosságát jelzô BODE-indexben használt BMI-értékkel is [14]. Centiméterszalaggal mértünk haskörfogatot és karkörfogatot minden betegnél.

Minden egyes betegnél megmértük a post-bronchodilator $\mathrm{FEV}_{1}$-értéket (az erôltetett kilégzés első másod-

\begin{tabular}{|c|c|c|c|}
\hline $\begin{array}{l}(\mathrm{C}) \\
\text { Magas kockázat } \\
\text { Kevés tünet }\end{array}$ & $\begin{array}{l}(\mathrm{D}) \\
\text { Magas kockázat } \\
\text { Több tünet }\end{array}$ & $\begin{array}{c}\geq 2 \\
\text { vagy } \\
\text { l kórházi }\end{array}$ & 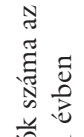 \\
\hline $\begin{array}{l}(\mathrm{A}) \\
\text { Alacsony kockázat } \\
\text { Kevés tünet }\end{array}$ & $\begin{array}{c}(\mathrm{B}) \\
\text { Alacsony kockázat } \\
\text { Több tünet }\end{array}$ & 1 & 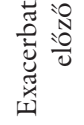 \\
\hline $\begin{array}{c}\text { mMRC: } 0-1 \\
\text { CAT<10 }\end{array}$ & $\begin{array}{c}m M R C \geq 2 \\
C A T \geq 10\end{array}$ & & \\
\hline
\end{tabular}

\begin{tabular}{l|l} 
1. ábra & A COPD GOLD súlyossági stádiumai
\end{tabular}

CAT $=$ COPD állapotfelmérő teszt $; \mathrm{COPD}=$ krónikus obstruk tív tüdőbetegség; GOLD = a COPD súlyossági fokát besoroló nemzetközi ajánlás; $\mathrm{mMRC}=$ a Brit Mellkasi Társaság módosított nehézlégzésskálája

percében kifújt volumen), és a becsült értékek százalékában fejeztük ki. A betegeket kizártuk, ha kórtörténetükben asztma fordult elö, és/vagy a $\mathrm{FEV}_{1}$ értéke több mint 12\%-kal vagy $200 \mathrm{ml}$-rel emelkedett a hörgőtágítás után. A betegeket $\mathrm{FEV}_{1} \mathrm{~A}-\mathrm{D}$ stádiumba soroltuk az aktuális és a jövőbeli kockázat paraméterei alapján a spirometriás értékek, a tünetek és az exacerbatiós ráta szerint (1. ábra) [2].

Az életminőség mérésére a betegségspecifikus SzentGyörgy-féle Légzési Kérdő́ív (SGRQ-C) [15] magyar nyelvre validált változatát használtuk, mely 40 kérdést tartalmaz. Az életminőséget befolyásoló tényezőket három kategóriába osztva vizsgálja: tüneti, aktivitási és a tüdőbetegség mindennapi életre gyakorolt hatását vizsgáló szegmens. Az egyes válaszok súlyszámértéke alapján számolhatók a különböző dimenziók súlyszámai, valamint az ezek összegéből adódó összpontszám értéke. Ennél a kérdőívnél a magasabb pontértékek alacsonyabb életminőséget jeleznek. A kérdőívet a beteg stabil állapotban az intézményben töltötte ki koordinátor felügyelete mellett. A 6 perces séta (6MWD) alkalmával a betegeket arra kértük, hogy 6 percig sétáljanak a folyosón, és ennek során detektáltuk a maximális sétatávolságot [16]. Minden beteg kitöltötte az mMRC-kérdőívet is [17], amellyel a nehézlégzés súlyosságát ítéljük meg. A kapott pontszámok alapján súlyossági kategóriákat alkottunk: enyhe (mMRC-pontszám: 0-1), moderált (mMRCpontszám: 2-3) és súlyos dyspnoe (mMRC-pontszám: 4). Ezenkívül egy saját fejlesztésú kérdőívet is kitöltöttek betegeink, amely a dohányzási és a táplálkozási szokásokra kérdezett rá. Éhomi vérmintát gyújtöttünk az Országos Korányi Pulmonológiai Intézet központi laboratóriumában a szérumlipidprofil (teljes koleszterin, trigliceridek, LDL és HDL) meghatározására. Szérumösszfehérje-, szérumalbumin- és prealbuminérték nem állt rendelkezésünkre. A vérvételi vizsgálatot a betegek klinikailag stabil, lázmentes és légúti fertőzéstől mentes állapotában végeztük. 
1. táblázat | A COPD-s betegek jellemzői BMI-kategóriák szerint

\begin{tabular}{|c|c|c|c|c|}
\hline & $\begin{array}{c}\text { Alultáplált } \\
\text { BMI }<21 \mathrm{~kg} / \mathrm{m}^{2} \\
\mathrm{n}=35\end{array}$ & $\begin{array}{c}\text { Normál testsúlyú } \\
\text { BMI } 21-25 \mathrm{~kg} / \mathrm{m}^{2} \\
\mathrm{n}=24\end{array}$ & $\begin{array}{c}\text { Túlsúlyos/Elhízott } \\
\text { BMI>25 kg/m² } \\
\mathrm{n}=5 \mathrm{l}\end{array}$ & p-érték \\
\hline Kor (év) (IQR) & $65,3(58-70)$ & $65,5(62-73)$ & $68,5(62-72)$ & 0,413 \\
\hline Férfi (fó, \%) & $20(58,82)$ & $14(58,33)$ & $20(39,21)$ & 0,188 \\
\hline Nő (fö, \%) & $15(42,85)$ & $10(41,66)$ & $31(60,78)$ & \\
\hline \multicolumn{5}{|l|}{ Dohányzási státusz } \\
\hline Aktívan dohányzó (fó, \%) & $18(51,43)$ & $9(37,5)$ & $23(44,23)$ & 0,290 \\
\hline Nem dohányzó (f"o, \%) & $17(48,57)$ & $15(62,5)$ & $28(54,90)$ & \\
\hline Dohányzott (fö, \%) & $35(100,00)$ & $22(91,66)$ & $49(96,07)$ & \\
\hline Dohányzás (év) & $42(38-50)$ & $40(35-50)$ & $40(30-50)$ & 0,754 \\
\hline Cigaretták száma (szál/nap) & $20(15-25)$ & $15(10-20)$ & $19,5(10-20)$ & 0,013 \\
\hline \multicolumn{5}{|l|}{ Izom $(\%)$} \\
\hline Férfi (\%) & $33,95(27,1-42,5)$ & $33,95(29-35,7)$ & $32,52(27,6-34,8)$ & 0,426 \\
\hline Nő (\%) & $32,55(26,6-39)$ & $28,25(24-31)$ & $30,15(25-33)$ & 0,136 \\
\hline \multicolumn{5}{|l|}{ Testzsír (\%) } \\
\hline Férfi (\%) & $18,5(12,1-33,2)$ & $27,45(18,1-36)$ & $34,44(31,6-38,9)$ & $<0,001$ \\
\hline Nő (\%) & $32,11(20-39)$ & $33,75(29,6-40)$ & $41,55(36,2-46)$ & 0,041 \\
\hline Alapanyagcsere (kcal) & $1324(1131-1385)$ & $1469(1360-1744)$ & $1432(1280-1615)$ & 0,004 \\
\hline \multicolumn{5}{|l|}{ Haskörfogat } \\
\hline Férfi $(\mathrm{cm})$ & $82(77-85)$ & $96(91-102)$ & $120(108-123)$ & $<0,001$ \\
\hline Nő $(\mathrm{cm})$ & $82(78,5-89)$ & $94(86,5-102)$ & $110(103-118)$ & $<0,001$ \\
\hline Karkörfogat $(\mathrm{cm})$ & $24(20-28)$ & $27(24-33)$ & $32(28-36)$ & 0,023 \\
\hline \multicolumn{5}{|l|}{ Összkoleszterin } \\
\hline Férfi $(\mathrm{mmol} / \mathrm{l})$ & $4,15(3,7-4,8)$ & $5,11(4,4-6)$ & $5,50(4,9-6)$ & 0,022 \\
\hline Nő (mmol/l) & $5,00(4,7-5,6)$ & $4,95(4,3-5,2)$ & $5,60(4,6-6,3)$ & 0,647 \\
\hline \multicolumn{5}{|l|}{ LDL-koleszterin } \\
\hline Férfi $(\mathrm{mmol} / \mathrm{l})$ & $2,41(1,88-3,13)$ & $2,82(2,54-3,14)$ & $3,35(2,85-4)$ & 0,064 \\
\hline Nő (mmol/l) & $3,09(2,44-3,55)$ & $2,74(2,2-3,5)$ & $3,3(2,6-4)$ & 0,451 \\
\hline \multicolumn{5}{|l|}{ HDL-koleszterin } \\
\hline Férfi $(\mathrm{mmol} / \mathrm{l})$ & $1,29(1,22-1,79)$ & $1,41(1-1,49)$ & $1,49(1-1,79)$ & 0,982 \\
\hline Nő (mmol/l) & $1,50(1,42-1,83)$ & $1,61(1,45-1,73)$ & $1,53(1,39-1,76)$ & 0,992 \\
\hline \multicolumn{5}{|l|}{ Triglicerid } \\
\hline Férfi $(\mathrm{mmol} / \mathrm{l})$ & $1,05(0,85-1,55)$ & $1,31(1,2-2,2)$ & $1,50(1,3-2,2)$ & 0,076 \\
\hline Nő (mmol/l) & $1,21(1-1,4)$ & $1,35(1,1-1,9)$ & $1,45(1,15-2,2)$ & 0,152 \\
\hline $\mathrm{FEV}_{1}(\mathrm{ref} \%)$ & $36(29-49)$ & $46(35-52)$ & $46(39-57)$ & 0,049 \\
\hline FVC (\%) & $64(54-78)$ & $72(59-90)$ & $67(56-75)$ & 0,465 \\
\hline $\mathrm{FEV}_{1} / \mathrm{FVC}(\%)$ & $44(38-52)$ & $47(43-62)$ & $56(48-65)$ & 0,001 \\
\hline \multicolumn{5}{|l|}{ GOLD-csoportok } \\
\hline GOLD A (f", \%) & $1(2,86)$ & $4(16,66)$ & $2(3,92)$ & 0,019 \\
\hline GOLD B (f", \%) & $7(20)$ & $5(20,83)$ & $17(33,33)$ & \\
\hline GOLD C (fo, \%) & $18(50,43)$ & $11(45,83)$ & $25(49,01)$ & \\
\hline GOLD D (f", \%) & $9(25,71)$ & $4(16,66)$ & $7(13,72)$ & \\
\hline Enyhe dyspnoe (mMRC: $0-1$ ) & 8 & 10 & 19 & 0,123 \\
\hline Moderált dyspnoe (mMRC: $2-3$ ) & 19 & 12 & 19 & \\
\hline Súlyos dyspnoe (mMRC: 4) & 8 & 2 & 13 & \\
\hline SGRQ-C tünet & 70,41 & 68,66 & 56,76 & 0,298 \\
\hline SGRQ-C aktivitás & 70,62 & 61,45 & 53,42 & 0,026 \\
\hline SGRQ-C hatás & 63,70 & 54,33 & 48,77 & 0,034 \\
\hline SGRQ-C totál & 65,63 & 56,59 & 47,23 & 0,045 \\
\hline 6MWD $(\mathrm{m})$ & $285(182-360)$ & $327(218-397)$ & $291(200-355)$ & 0,037 \\
\hline Exacerbatiók az előző évben & $2(0-4)$ & $1(1-3)$ & $1(0-3)$ & 0,023 \\
\hline Szteroidhasználat az előző évben & $2(1-4)$ & $1(0-2)$ & $2(1-3)$ & 0,022 \\
\hline
\end{tabular}

A táblázat adatai medián és interkvartilis terjedelemben kerültek bemutatásra.

$6 \mathrm{MWD}=6$ perces sétatávolság; $\mathrm{BMI}=$ testtömegindex; $\mathrm{FEV}_{1}=$ erőltetett kilégzés első másodpercében kifújt volumen; $\mathrm{COPD}=$ krónikus obstruktív tüdőbetegség; $\mathrm{FVC}=$ forszírozott vitálkapacitás; $\mathrm{GOLD}=$ a COPD súlyossági fokát besoroló nemzetközi ajánlás; $\mathrm{HDL}=$ magas sűrúségú lipoprotein; $\mathrm{IQR}=$ interkvartilis terjedelem; $\mathrm{LDL}=$ alacsony sürúségú lipoprotein; $\mathrm{mMRC}$ = a Brit Mellkasi Társaság módosított nehézlégzésskálája; SGRQ = Szent-György-féle Légzési Kérdő́iv; szignifikanciaszint: p $<0,05$ 


\section{Statisztikai analízis}

A statisztikai elemzéseket a STATA SE-10.0 (StataCorp, College Station, TX, USA) programcsomaggal végeztük, leíró elemzéseket, korrelációs analízist végeztünk (egyváltozós, Spearman-féle rangkorrelációs teszttel). A minta eloszlását Shapiro-Wilk-teszttel ellenőriztük; a folytonos változók nem normáleloszlást mutattak, ezért medián és interkvartilis terjedelemben adtuk meg a táblázatok adatait. Nem parametrikus próbát (KruskalWallis-próba) alkalmaztunk a különböző csoportok öszszehasonlítására. A statisztikai teszteket 95\%-os konfidenciaintervallum mellett végeztük, a szignifikancia értéke $\mathrm{p}<0,05$ volt.

\section{Eredmények}

Összesen 110 COPD-s betegnél végeztük el a tápláltsági állapot rizikójának kombinált szűrését. Közülük 75 fơnél (68\%) nem diagnosztizáltuk a kóros tápláltsági állapot kialakulásának rizikóját sem a MUST-, sem a BIA-módszer alapján, 35 fónél (32\%) legalább az egyik módszer rizikót jelzett. A MUST-kérdőív által jelzett rizikós beteg 30 fó (27\%) volt, míg az InBody géppel mérve 35 fó (32\%) volt kiszűrve malnutritióra. A betegek jellemzői medián és interkvartilis terjedelemben: medián életkor: 66 (IQR 61-72) év; testmagasság: 165,5 (IQR 158173 ) cm; testtömeg: 65 (IQR 54-80) kg; BMI: 24,48 (IQR 19,17-29,74) kg/m². Majdnem az összes beteg $(96,4 \%)$ dohányzó volt, a dohányzással töltött évek száma 40 (IQR 30-50) év, az átlagosan elszívott cigarettaszám 20 (IQR 10-30) szál/nap. Az átlagos $\mathrm{FEV}_{1}$ ref\% 44 (IQR 32-54) volt; GOLD A csoportba soroltuk a betegek 6,4\%-át, GOLD B-be a betegek egynegyedét $(25,4 \%)$, GOLD C-be a betegek felét $(50,0 \%)$ és GOLD D-be a betegek 18,2\%-át. Az alultáplált betegek tüdőfunkciója gyengébb volt ( $\mathrm{FEV}_{1} \mathrm{ref} \%$ : 36 [IQR 29-49]), mint a normál táplált ( $\mathrm{FEV}_{1}$ ref\%: 46 [IQR 35-52]) vagy a túlsúlyos/elhízott ( $\mathrm{FEV}_{1} \mathrm{ref} \%: 46$ [IQR 39-57]) betegek körében. A betegek közel fele (45\%) az előző 12 hónapban bekövetkezett súlycsökkenésről számolt be, átlagosan 3,1 kg-ot vesztettek a súlyukból.

A mért testtömegból és testmagasságból kalkulált testtömegindex-értékek átlagai a vizsgált minta 21,8\%-ánál (24 fö) normál-BMI-értéket mutatott, alacsony testtömegindexszel $\left(\mathrm{BMI}<21 \mathrm{~kg} / \mathrm{m}^{2}\right)$ a betegek egyharmada rendelkezett $(31,8 \%)$; ezen a kategórián belül a $\mathrm{BMI}$ $<18,5 \mathrm{~kg} / \mathrm{m}^{2}$ volt 18 fó esetében (11 férfi, 7 nö). Magas volt a BMI-je $\left(\mathrm{BMI}>25 \mathrm{~kg} / \mathrm{m}^{2}\right)$ a betegek csaknem felének $(46,4 \%)$. A betegek antropometriai jellemzőit a BMI szerint csoportosítva az 1 . táblázatban részletesen bemutatjuk.

Az alultáplált betegek szignifikánsan alacsonyabb testzsírszázalékkal (férfi: 18,5 vs. 34,4; p<0,001; nő: 32,11 vs. 41,$55 ; \mathrm{p}=0,041)$ és a férfiak esetében szignifikánsan alacsonyabb összkoleszterinszinttel (férfi: 4,15 vs. 5,50; $\mathrm{p}=0,022$; nő: 5,00 vs. 5,$60 ; \mathrm{p}=0,647)$ rendelkeztek, mint normál- vagy túlsúllyal rendelkező társaik. Az alultáplált betegek kevésbé voltak terhelhetők (6MWD [m] 285 vs. 327 vs. 291; p =0,037), és szignifikánsan magasabb volt az exacerbatiók ( 2 vs. $1 ; \mathrm{p}=0,023$ ), valamint a szteroidok használatának száma ( 2 vs. $1 ; \mathrm{p}=0,022)$, mint a normál- vagy túlsúllyal rendelkező betegek esetében (1. táblázat).

Az SGRQ-C összpontszáma 65,63 vs. 56,59 vs. 47,23 volt; az alultáplált betegek esetében szignifikánsan magasabbak voltak az SGRQ-C pontszámai, melyek gyengébb életminőséget jeleznek mind az aktivitás ( $\mathrm{p}=$ $0,026)$, mind a hatás $(\mathrm{p}=0,034)$ és az összes pontszám $(\mathrm{p}=0,045)$ tekintetében, mint a normál- vagy túlsúllyal rendelkezők körében (1. táblázat).

Az alultápláltság $\left(B M I<21 \mathrm{~kg} / \mathrm{m}^{2}\right)$ prevalenciája magasabb volt a súlyos/nagyon súlyos COPD-ben szenvedőknél, mint az enyhe/közepesen súlyos COPD-ben. Az izomszázalék és a tüdőfunkció kapcsolatát vizsgálva, a magasabb izomszázalékszinttel rendelkező betegek jobb tüdőfunkciós értékeket mutattak (2. táblázat).

A BMI és $\mathrm{FEV}_{1}$ (ref \%) értékei közti összefüggés szoros volt, a BMI emelkedésével a $\mathrm{FEV}_{1}$-értékek emelkedése figyelhetô meg (3. táblázat). Az összefüggés nemenkénti bontásban is igazolható, a korreláció értéke:

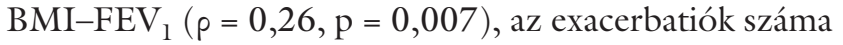
és a BMI között $(\rho=0,37, p=0,008)$.

Korrelációvizsgálatot végeztünk a tápláltsági állapot, a terhelhetőség (6MWD) és a légúti tünetek között is (4. táblázat). Eredményeink alapján elmondható, hogy a légszomjskála (mMRC) szignifikáns korrelációt mutat a mért paraméterekkel, a 6 perces sétatávolsággal $(p=$ $-0,47, \mathrm{p}<0,001), \operatorname{aFEV}_{1}(\operatorname{ref} \%)-\operatorname{kal}(\rho=-0,27, \mathrm{p}=0,005)$ és az alapanyagcserével $(\rho=-0,24, p=0,011)$ is.

A betegek táplálkozási szokásaiból szeretném kiemelni, hogy a kutatásban részt vevók közel fele (44,3\%) egyáltalán nem fogyaszt halat, bárminemü húsfélét $(42,8 \%)$, tejtermékeket $(32,3 \%)$, aminek egyik oka lehet a laktózintolerancia is $(4,0 \%)$. Ez azt jelenti, hogy a fehérjében gazdag ételek nagyon alacsony arányban vannak jelen a COPD-s betegek étkezésében. Rossz vagy változó étvágyról számolt be a betegek csaknem fele (48,2\%), rágási nehezítettségről a betegek csaknem egynegyede $(22,8 \%)$, míg a nyelés nehezítettségéról a betegek 10\%-a.

\section{Megbeszélés}

Tanulmányunk célja volt felmérni 110, COPD-s beteg tápláltsági állapotát kombinált rizikószứréssel (MUST és BIA) és leírni annak az életminőséggel való kapcsolatát. Eredményeink alapján elmondható, hogy a COPD súlyosabb stádiumaiban a betegek tápláltsági állapota roszszabb, mint a betegség enyhébb kategóriáiban. Megállapítottuk, hogy az alultáplált COPD-s betegek gyengébb tüdőfunkcióval és rosszabb életminőséggel rendelkeznek, és kevésbé terhelhetők, mint normál/túlsúlyos társaik, valamint azt is, hogy azok a betegek, akik magasabb 
2. táblázat |A COPD-s betegek súlyossági osztályozása és ennek megfelelően a paraméterek összehasonlítása GOLD-stádiumok szerint

\begin{tabular}{|c|c|c|c|c|c|}
\hline & $\begin{array}{c}\text { GOLD A } \\
\mathrm{n}=7\end{array}$ & $\begin{array}{c}\text { GOLD B } \\
\mathrm{n}=28\end{array}$ & $\begin{array}{c}\text { GOLD C } \\
\mathrm{n}=55\end{array}$ & $\begin{array}{c}\text { GOLD D } \\
\mathrm{n}=20\end{array}$ & p-érték \\
\hline Kor (év) (IQR) & $71(60-72)$ & $69(57-73)$ & $67(63-72)$ & $63(56-70)$ & 0,382 \\
\hline Férfi (fö, \%) & $3(42,85)$ & $13(46,42)$ & $27(49,09)$ & $12(60,0)$ & 0,593 \\
\hline Nő (fö, \%) & $4(57,15)$ & $15(53,57)$ & $28(50,91)$ & $8(40,0)$ & \\
\hline $\operatorname{BMI}\left(\mathrm{kg} / \mathrm{m}^{2}\right)$ & $26,9(19,5-30,2)$ & $23,8(20,6-27,2)$ & $23,1(18,9-20,2)$ & $21,8(19,3-27,3)$ & 0,048 \\
\hline \multicolumn{6}{|l|}{$\mathrm{BMI}<21 \mathrm{~kg} / \mathrm{m}^{2}$} \\
\hline Férfi (fö, \%) & $1(14,28)$ & $3(10,71)$ & $9(16,36)$ & $0(0)$ & 0,180 \\
\hline Nő (fö, \%) & $0(0)$ & $4(14,28)$ & $9(16,36)$ & $9(45,0)$ & \\
\hline \multicolumn{6}{|l|}{ Izom $(\%)$} \\
\hline Férfi (\%) & $33(30-36)$ & $34(27-37)$ & $32(28-39)$ & $25(24-28)$ & 0,274 \\
\hline Nő (\%) & $30(24-39)$ & $32(26-34)$ & $29(24-31)$ & $28(24-31)$ & 0,614 \\
\hline \multicolumn{6}{|l|}{ Testzsír (\%) } \\
\hline Férfi (\%) & $33,4(25,2-39,2)$ & $30,2(19,3-36,0)$ & $31,2(18,2-36,3)$ & $26,0(15,1-37,2)$ & 0,824 \\
\hline Nő (\%) & $34,4(32,4-38,5)$ & $39,8(26,7-43,6)$ & $38,1(29,6-45,1)$ & $35,6(32,1-47,3)$ & 0,899 \\
\hline Alapanyagcsere (kcal) & $1337(1312-1710)$ & $1426(1309-1648)$ & $1375(1264-1500)$ & $1381(1248-1655)$ & 0,214 \\
\hline Összkoleszterin $(\mathrm{mmol} / \mathrm{l})$ & $5(3,9-5,9)$ & $5(4,5-6)$ & $5(3,9-5,8)$ & $6(4,7-6,4)$ & 0,391 \\
\hline LDL-koleszterin & $2,9(2,4-3,6)$ & $3(2,6-3,5)$ & $2,6(2,1-3,5)$ & $4(2,4-4,6)$ & 0,405 \\
\hline HDL-koleszterin & $1,4(1-1,6)$ & $1,5(1,2-1,8)$ & $1,5(1,3-1,8)$ & $1,6(1,2-1,7)$ & 0,606 \\
\hline Triglicerid (mmol/l) & $1,3(0,1-1,4)$ & $1,6(1,1-2,2)$ & $1,3(0,1-1,7)$ & $1,4(0,7-2)$ & 0,171 \\
\hline $6 \mathrm{MWD}(\mathrm{m})$ & $360(240-420)$ & $300(212-452)$ & $284(210-330)$ & $225(142-335)$ & 0,018 \\
\hline $\mathrm{FEV}_{1}\left(\mathrm{ref}_{0}\right)$ & $93(89-100)$ & $58(53-65)$ & $41(35-46)$ & $26(23-29)$ & $<0,001$ \\
\hline FVC (\%) & $114(109-121)$ & $77(69-90)$ & $64(59-71)$ & $52(48-55)$ & $<0,001$ \\
\hline
\end{tabular}

A táblázat adatai medián és interkvartilis terjedelemben kerültek bemutatásra.

$6 \mathrm{MWD}=6$ perces sétatávolság; $\mathrm{BMI}=$ testtömegindex; $\mathrm{FEV}_{1}=$ erőltetett kilégzés első másodpercében kifújt volumen; FVC = forszírozott vitálkapacitás; GOLD = a COPD súlyossági fokát besoroló nemzetközi ajánlás; $\mathrm{HDL}$ = magas sưrúségú lipoprotein; $\mathrm{IQR}=$ interkvartilis terjedelem; $\mathrm{LDL}=$ alacsony sưrúségú lipoprotein; szignifikanciaszint: $\mathrm{p}<0,05$

3. táblázat |A BMI $\left(\mathrm{kg} / \mathrm{m}^{2}\right)$ korrelációja a demográfiai és különböző funkcionális paraméterekkel

\begin{tabular}{lcc|cc|ccc}
\hline & \multicolumn{2}{c|}{ Férfi } & \multicolumn{2}{c|}{ Nő } & \multicolumn{2}{c}{ Teljes } \\
\hline Változó & $p$ & p-érték & $\rho$ & p-érték & $p$ & p-érték \\
\hline Kor $($ év) & 0,14 & 0,301 & 0,10 & 0,480 & 0,13 & 0,197 \\
\hline FEV $_{1}($ ref\%) & 0,31 & 0,024 & 0,19 & 0,150 & 0,26 & 0,007 \\
\hline 6MWD $(\mathrm{m})$ & 0,16 & 0,245 & $-0,11$ & 0,420 & 0,09 & 0,496 \\
\hline mMRC & $-0,33$ & 0,015 & 0,08 & 0,577 & $-0,12$ & 0,225 \\
\hline Dohányzás (év) & $-0,21$ & 0,133 & 0,05 & 0,733 & $-0,04$ & 0,664 \\
\hline Exacerbatiók száma az előző évben & 0,37 & 0,006 & 0,36 & 0,009 & 0,37 & 0,008 \\
\hline
\end{tabular}

$6 \mathrm{MWD}=6$ perces sétatávolság; $\mathrm{BMI}=$ testtömegindex; $\mathrm{FEV}_{1}=$ erőltetett kilégzés első másodpercében kifújt volumen; FVC = forszírozott vitálkapacitás; $m M R C=a$ Brit Mellkasi Társaság módosított nehézlégzésskálája; $\rho=$ Spearman-féle korrelációs együttható; szignifikanciaszint: $p<0,05$

izomszázalékkal rendelkeznek, jobb tüdőfunkciós értékeket mutatnak. Az alultápláltság prevalenciája magas, életkortól és nemtől függetlenül, mintánkban 31,8\%, amit több tényező magyarázhat. Egyrészt a kórházba kerülő COPD-s betegek kockázata alultápláltságra magasabb, mint a nem kórházba kerülő társaiké, másrészt jelen vizsgálatunkban a malnutritio határértéke 21-es
BMI-érték volt, mely tágabb a WHO-klasszifikáció szerinti 18,5-ös határértéknél. Ennek oka, hogy krónikus betegek esetében már 21-es BMI-érték alatt fokozódik a halálozás kockázata $[13,14]$, és mielőbbi táplálásterápia bevezetése indokolt a szakmai irányelvek szerint; ezt támasztja alá a BODE-index és az NHLBI-osztályozás is [18-21]. 
4. táblázat |Az mMRC-dyspnoeskála korrelációja a demográfiai és különböző funkcionális paraméterekkel

\begin{tabular}{|c|c|c|c|c|c|c|}
\hline & \multicolumn{2}{|c|}{ Férfi } & \multicolumn{2}{|c|}{ Nő } & \multicolumn{2}{|c|}{ Teljes } \\
\hline Változó & $p$ & p-érték & $p$ & p-érték & $p$ & p-érték \\
\hline $\mathrm{FEV}_{1}(\mathrm{ref} \%)$ & $-0,38$ & 0,004 & $-0,17$ & 0,228 & $-0,27$ & 0,005 \\
\hline FVC (\%) & $-0,23$ & 0,102 & $-0,14$ & 0,327 & $-0,19$ & 0,047 \\
\hline Izom (\%) & 0,07 & 0,633 & $-0,24$ & 0,073 & $-0,08$ & 0,382 \\
\hline Testzsír (\%) & $-0,19$ & 0,179 & 0,10 & 0,467 & 0,00 & 0,983 \\
\hline Alapanyagcsere (kcal) & $-0,38$ & 0,004 & $-0,10$ & 0,468 & $-0,24$ & 0,011 \\
\hline 6MWD (m) & $-0,56$ & $<0,001$ & $-0,39$ & 0,004 & $-0,47$ & $<0,001$ \\
\hline
\end{tabular}

$6 \mathrm{MWD}=6$ perces sétatávolság; $\mathrm{FEV}_{1}=$ eróltetett kilégzés első másodpercében kifújt volumen; FVC = forszírozott vitálkapacitás; mMRC = a Brit Mellkasi Társaság módosított nehézlégzésskálája; $\rho$ = Spearman-féle korrelációs együttható; szignifikanciaszint: $p<0,05$

Kutatások leírják $[22,23]$, hogy a cigarettafüstben levő nikotin az anyagcsere növelésével csökkenti a testtömeget, csökkenti az étvágyat és az energia felszívódását is, ezáltal elősegíti a fogyást. Mintánkban a valaha dohányzók $(96,4 \%)$ és a jelenleg aktív dohányosok aránya is magas $(45,5 \%)$, ami magyarázó tényező lehet, mert minél hosszabb és súlyosabb a nikotinfüggőség, annál nagyobb az alultápláltság kockázata. Ezenkívül a dohányzással töltött átlagos évek száma a legmagasabb azok között, akiknél a legsúlyosabb az alultápláltság. Ez felhívja a figyelmet arra, hogy a COPD diagnózisának már korai szakaszában a dohányzás abbahagyására vonatkozó tanácsok beillesztése mellett rutinszerúen meg kell ismételni a táplálkozási tanácsokat is [24].

A tápláltsági állapot fontos tényezője a COPD kifejlődésének. Kimutatták, hogy a kór előrehaladtával a COPD-ben szenvedő betegekre és különösen a súlyos betegekre nézve veszélyt jelent az alultápláltság, mely azt a lehetőséget rejti magában, hogy a korai beavatkozás alacsony BMI-vel rendelkező betegekben csökkentheti a betegség kifejlődését [25]. Bebizonyosodott, hogy az alacsony BMI a súlyos betegek körében a halálozás független kockázati tényezője, mert romlik a szervezet védekezőképessége, csökken a légzőizmok ereje, csökken a vitálkapacitás, romlik a gázcsere, a vesében csökken a filtráció, a bélfal sorvadása további felszívódási és emésztési zavarokhoz vezethet [26]. A testsúly növelése javítja a légzőizmok teljesítményét, az erősebb légzőiizmok csökkenthetik az akut exacerbatiók számát, javítják a ventilációt és a betegek terhelhetőségét is [27, 28].

A vizsgálatunkban részt vevők csaknem fele $(44,5 \%)$ súlycsökkenést tapasztalt és átlagosan $3,1 \mathrm{~kg}$-ot vesztett az előző 12 hónapban; ez összhangban áll a korábbi vizsgálatokkal, amelyekben azt találták, hogy enyhe COPD esetén kb. 10-15\%-ban, míg súlyos COPD-ben a betegek kb. felénél tapasztalnak súlyvesztést [29]. Figyelemre méltó, hogy a súlyosan alultáplált résztvevők nagyobb súlycsökkenést tapasztaltak, mint azok, akik enyhén alultápláltak. A vizsgálat keresztmetszeti jellege miatt nem egyértelmú, hogy folytatódott-e a betegeknél a további fogyás.
Számos tanulmány rámutatott arra, hogy a 2,0 kg-os vagy annál nagyobb súlygyarapodás javítja a COPD-s betegek terhelhetőségét és életminőségét, így a táplálásterápia egyik elsődleges célja kell, hogy legyen a fogyás megelőzése [30]. Javasolt a magas kalóriatartalmú, fehérjedús táplálék fogyasztása [31]; sajnos korábbi tanulmányok rámutatnak arra, hogy a résztvevők többségének étkezése (több mint 80\%) nem fedezi testük energia- és fehérjeigényét $[31,32]$. Hangsúlyozni kell a napi többszöri étkezés fontosságát és az ételek sokszínúségének ösztönzését, mely előnyös lehet a COPD-s betegek számára a fogyás megelőzésében, a súlygyarapodás előmozdításában és a tápláltsági állapot javításában.

Tanulmányunk arra is rávilágít, hogy a tápláltsági állapot összefüggésben van a tüdőfunkcióval és a betegek életminőségével. Korábbi tanulmányok beszámoltak a táplálkozási beavatkozások hatékonyságáról a COPD-s betegek terhelési toleranciájának és életminőségének javítása érdekében $[33,34]$. Szakmai ajánlások alapján a 21-nél alacsonyabb BMI táplálásterápiát indokol; az oralis táplálékfelvétel emelése mellett nagy energiatartalmú tápszerekkel lehet/kell a diétát kiegészíteni, s fontos, hogy a mellette alkalmazott terheléses tréning fokozza a táplálásterápia hatását [35-39]. A rehabilitáció fontos szerepet kap e betegek életminőségének javításában [3539]. A táplálkozási tanácsadásnak a következő kulcsfontosságú üzeneteket kell tartalmaznia: többféle élelmiszerből válasszon a beteg minden nap, különös tekintettel a fehérjében gazdag ételekre, például húsra, baromfira, a tenger gyümölcseire, tojásra, tejre, olajos magvakra; válasszon olyan energia- és fehérjegazdag ételeket, amelyek helyben rendelkezésre állnak, és a három fóétkezés mellé iktasson be kisebb étkezéseket is [40].

A COPD progressziójában jelentős szerepet játszik a tápláltsági állapot, ezáltal a kezelés lényeges részét kell, hogy képezze a dietoterápia. A jó tápláltsági állapottal rendelkező betegeknek nagyobb az esélyük egészségi állapotuk megórzésére és annak javulására, amely hatással van az életminőségükre, ugyanakkor a kedvezőtlen tápláltsági állapot csökkenti az életben maradási esélyt [40]. A malnutritio felfedése és a megfelelő tápláltsági állapot kialakítása nagyon fontos az optimális terápiás kezelés- 
ben [40]. A COPD-ben szenvedő betegek esetében kb. 6-12 havonta kontrollálni kell a súlycsökkenést, mert megfelelő étrenddel, valamint rendszeres testmozgással javítható a betegek életminősége.

Kutatásunk korlátai közé tartozik az alacsony esetszám és az egycentrumos bevonás, ezért további vizsgálatok és adatelemzések szükségesek ahhoz, hogy a fenti megállapítások tudományos megalapozottságot nyerjenek, és a széles körü gyakorlatban elterjedhessenek.

\section{Következtetés}

A COPD-s betegek a betegségük gyulladásos jellegéből adódóan és a beszúkült étrend miatt különösen veszélyeztetettek a kóros tápláltsági állapot kialakulásában. Az alacsony testtömeg jelentősen befolyásolhatja betegségük kimenetelét, a kórházi tartózkodás hosszát. A kóros tápláltsági állapot kialakulásának magas rizikója miatt fontos a járóbeteg-gondozásban részesülők szürése is, a szûrőmódszerek eltérő eredményessége miatt pedig javasoljuk kombinált módszerek (MUST és BIA) egyidejü alkalmazását. A kiszúrt betegeknél javasoljuk a táplálásterápia hatékonyságának rendszeres követését.

Anyagi támogatás: A szerzők a cikk megírása, illetve a kutatómunka során anyagi támogatásban nem részesültek.

Szerzői munkamegosztás: F. M.: A kérdőív szerkesztése, feldolgozása és értékelése, irodalomkutatás, cikkírás. P. J., T. K., Sz. M., H. D.: A betegek kérdőívezése, géppel való lemérése, irodalomkutatás. Sz. G.: A statisztika ellenőrzése, cikkírás. V. J. T.: A kutatás felügyelete, a kézirat megszövegezése, ellenőrzése és végső formába öntése. A cikk végleges változatát valamennyi szerző elolvasta és jóváhagyta.

Érdekeltségek: A szerzőknek nincsenek érdekeltségeik.

\section{Köszönetnyilvánítás}

Köszönetet mondunk Veresné dr. Bálint Mártának, aki biztosította számunkra az InBody 170 testösszetétel-analizáló készüléket, az Országos Korányi Pulmonológiai Intézet dietetikusainak, akik lemérték az eszközökkel a betegeket, koordinátorunknak, Kecskés Anitának és az Országos Korányi Pulmonológiai Intézet betegeinek, akik értékes válaszaikkal segítették a kutatást.

\section{Irodalom}

[1] Varga JT. Chronic obstructive pulmonary disease. [Krónikus obstruktív tüdőbetegség.] Háziorv Továbbk Szle. 2018; 23: 54-58. [Hungarian]

[2] Global Strategy for the Diagnosis, Management and Prevention of COPD, Global Initiative for Chronic Obstructive Lung Disease (GOLD) 2019. Available from: http://goldcopd.org [accessed: March 20, 2020]
[3] Vogelmeier CF, Criner GJ, Martinez FJ, et al. Global strategy for the diagnosis, management and prevention of chronic obstructive lung disease 2017 report: GOLD executive summary. Respirology 2017; 22: 575-601.

[4] Korányi Bulletin 2019. [Korányi Bulletin 2019.] Országos Korányi Pulmonológiai Intézet, Budapest. Available from: http:// www.koranyi.hu/tartalom/bulletin/Evkonyv2019.pdf [accessed: March 21, 2020]. [Hungarian]

[5] Schols AM, Ferreira IM, Franssen FM, et al. Nutritional assessment and therapy in COPD: a European Respiratory Society statement. Eur Respir J. 2014; 44: 1504-1520.

[6] Odler B, Müller V. Asthma-COPD overlap syndrome. [AsthmaCOPD overlap szindróma.] Orv Hetil. 2016; 157: 1304-1313. [Hungarian]

[7] Collins PF, Stratton RJ, Kurukulaaratchy RJ, et al. Influence of deprivation on health care use, health care costs, and mortality in COPD. Int J Chron Obstruct Pulmon Dis. 2018; 13: 12891296.

[8] Tamási L, Speer G, AMULET vizsgálóorvosai. Assessment of patient-reported outcomes by questionnaires in patients with Moderate and severe chronic obstructive pulmonary disease treated with glycopyrroniUm in the reaL lifE setTing in Hungary (AMULET). [Glikopirróniummal kezelt középsúlyos és súlyos krónikus obstruktív tüdőbetegek állapotának kérdőíves értékelése valós körülmények között. AMULET-vizsgálat.] Orv Hetil. 2020; 161: 295-305. [Hungarian]

[9] Ter Beek L, van der Vaart H, Wempe JB, et al. Dietary resilience in patients with severe COPD at the start of a pulmonary rehabilitation program. Int J Chron Obstruct Pulmon Dis. 2018; 13: 1317-1324.

[10] Fekete M, Pongor V, Fehér A, et al. Relationship of chronic obstructive pulmonary disease and nutritional status - clinical observations. [Krónikus légzőszervi betegek tápláltsági állapotának vizsgálata - klinikai megfigyelések.] Orv Hetil. 2019; 160: 908913. [Hungarian]

[11] Rawal G, Yadav S. Nutrition in chronic obstructive pulmonary disease: a review. J Transl Int Med. 2015; 3: 151-154.

[12] Kondrup J, Allison SP, Elia M, et al. European Society of Parenteral and Enteral Nutrition (ESPEN) guidelines for nutrition screening 2002. Clin Nutr. 2003; 22: 415-421.

[13] National Institutes of Health, National Heart Lung and Blood Institute Obesity Education Initiative Expert Panel on the Identification, Evaluation, and Treatment of Obesity in Adults. Executive summary of the clinical guidelines on the identification, evaluation, and treatment of overweight and obesity in adults. Arch Intern Med. 1998; 158: 1855-1867.

[14] Celli BR, Cote CG, Marin JM, et al. The body-mass index, airflow obstruction, dyspnea, and exercise capacity index in chronic obstructive pulmonary disease. N Engl J Med. 2004; 350: 10051012 .

[15] Jones PW, Quirk FH, Baveystock CM, et al. A self-complete measure for health status for chronic airflow limitation. The St. George's Respiratory Questionnaire. Am Rev Respir Dis. 1992; 145: 1321-1327.

[16] ATS Committee on Proficiency Standards for Clinical Pulmonary Function Laboratories. ATS statement: guidelines for the sixminute walk test. Am J Respir Crit Care Med. 2002; 166: 111117. [Correction: Am J Respir Crit Care Med. 2016; 193: 1185.]

[17] Bestall JC, Paul EA, Garrod R, et al. Usefulness of the Medical Research Council (MRC) dyspnoea scale as a measure of disability in patients with chronic obstructive pulmonary disease. Tho$\operatorname{rax} 1999 ; 54$ : 581-586.

[18] Schols AM, Slangen J, Volovics L, et al. Weight loss is a reversible factor in the prognosis of chronic obstructive pulmonary disease. Am J Respir Crit Care Med. 1998; 157: 1791-1797.

[19] Böszörményi Nagy Gy, Balikó Z, Kovács G, et al. Protocol on diagnosis and therapy of the basic and emergency management 
of patients affected by chronic obstructive pulmonary disease. [Egészségügyi szakmai irányelv a krónikus obstruktív tüdőbetegség (COPD) diagnosztikájáról és kezeléséról az alap-, a szak és a sürgősségi ellátás területére.] Med Thor. 2014; 67(Suppl): 79-113. [Hungarian]

[20] Divo MJ, Cabrera C, Casanova C, et al. Comorbidity distribution, clinical expression and survival in COPD patients with different body mass index. Chronic Obstr Pulm Dis. 2014; 1: 229238.

[21] Ansari K, Keaney N, Kay A, et al. Body mass index, airflow obstruction and dyspnea and body mass index, airflow obstruction, dyspnea scores, age and pack years-predictive properties of new multidimensional prognostic indices of chronic obstructive pulmonary disease in primary care. Ann Thorac Med. 2016; 11: 261-268.

[22] Collins PF, Stratton RJ, Elia M. The influence of smoking status on malnutrition risk and 1-year mortality in outpatients with chronic obstructive pulmonary disease. J Hum Nutr Diet. 2011; 24: 382-383

[23] Audrain-Mcgovern J, Benowitz NL. Cigarette smoking, nicotine, and body weight. Clin Pharmacol Ther. 2011; 90: 164168 .

[24] Collins PF, Stratton RJ, Elia M. The influence of smoking status on malnutrition risk and l-year mortality in outpatients with chronic obstructive pulmonary disease. J Hum Nutr Diet. 2011; 24: 382-383.

[25] Rutten E, Wouters E, Franssen F. Malnutrition and obesity in COPD. Eur Respir Mon. 2013; 59: 80-92.

[26] Vanfleteren LE, Spruit MA, Wouters EF, et al. Management of chronic obstructive pulmonary disease beyond the lungs. Lancet Respir Med. 2016; 4: 911-924.

[27] Varga J. Smoking and pulmonary complications: respiratory prehabilitation. J Thorac Dis. 2019; 11(Suppl 5): S639-S644.

[28] Varga J, Munkácsi A, Máthé Cs, et al. The effect of the inspiratory muscles training on physical condition in COPD. [A belégzó izmok tréningjének hatása a betegek fizikai állapotára COPDben.] Med Thor. 2018; 71: 96-102. [Hungarian]

[29] Schols AM, Soeters PB, Dingemans AM, et al. Prevalence and characteristics of nutritional depletion in patients with stable COPD eligible for pulmonary rehabilitation. Am Rev Respir Dis. 1993; 147: 1151-1156.

[30] Jones PW, Brusselle G, Dal Negro RW, et al. Health-related quality of life in patients by COPD severity within primary care in Europe. Respir Med. 2011; 105: 57-66.
[31] Bauer J, Biolo G, Cederholm T, et al. Evidence-based recommendations for optimal dietary protein intake in older people: a position paper from the PROT-AGE Study Group. J Am Med Dir Assoc. 2013; 14: 542-559.

[32] Raynaud-Simon A, Revel-Delhom C, Hébuterne X. Clinical practice guidelines from the French Health High Authority: nutritional support strategy in protein-energy malnutrition in the elderly. Clin Nutr. 2011; 30: 312-319.

[33] Kwon HY, Kim E. Factors contributing to quality of life in COPD patients in South Korea. Int J Chron Obstruct Pulmon Dis. 2016; 11: 103-109.

[34] Suzana S Jr, Hanis MY, Tang SY, et al. Changes in nutritional, functional status and quality of life of COPD out-patients after a pulmonary rehabilitation programme in HUKM: a pilot study. Malays J Nutr. 2008; 14: 151-162.

[35] Vágvölgyi A, Rozgonyi Z, Vadász P, et al. Risk stratification before thoracic surgery, perioperative pulmonary rehabilitation. [A mellkassebészeti mútéti teherbíró képesség megítélése, perioperatív légzésrehabilitáció.] Orv Hetil. 2017; 158: 1989-1997. [Hungarian]

[36] Vágvölgyi A, Rozgonyi Z, Kerti M, et al. Effectiveness of pulmonary rehabilitation and correlations in between functional parameters, extent of thoracic surgery and severity of post-operative complications: randomized clinical trial. J Thor Dis. 2018; 10: 3519-3531.

[37] Varga J, Pálinkás A, Lajko I, et al. Pulmonary arterial pressure response during exercise in COPD: A correlation with C-reactive protein (hsCRP). Open Respir Med J. 2016; 10: 1-11.

[38] Varga J. Porszasz J, Boda K, et al. Supervised high intensity continuous and interval and home training effect in the rehabilitation of chronic obstructive pulmonary patients. [Felügyelt magas intenzitású folyamatos és intervallum, valamint otthoni tréning hatásának vizsgálata krónikus obstruktív tüdőbetegek rehabilitációjában.] Med Thor. 2008; 61: 135-143. [Hungarian]

[39] Pákó J, Barta I, Balogh Z, et al. Assessment of the anti-aging klotho protein in patients with COPD undergoing pulmonary rehabilitation. COPD 2017; 14: 176-180.

[40] Eyles HC, Mhurchu CN. Does tailoring make a difference? A systematic review of the long-term effectiveness of tailored nutrition education for adults. Nutr Rev. 2009; 67: 464-480.

(Fekete Mónika dr., Budapest, Nagyvárad tér 4., 1089 e-mail: fekete.monika@med.semmelweis-univ.hu)

A cikk a Creative Commons Attribution 4.0 International License (https://creativecommons.org/licenses/by/4.0/) feltételei szerint publikált Open Access közlemény melynek szellemében a cikk bármilyen médiumban szabadon felhasználható, megosztható és újraközölhető, feltéve, hogy az eredeti szerző és a közlés helye, illetve a CC License linkje és az esetlegesen végrehajtott módosítások feltüntetésre kerülnek. (SID_1) 